\title{
Thinning in natural forests: an experience from Nepalgunj Forest Development Project
}

\author{
D.P. Parajuli ${ }^{1}$ and S. M. Amatya ${ }^{2}$
}

$\mathrm{T}$ hinning is one of the important silvicultural operations, which aims at overall growth of the remaining stands. Thinning operations, especially in natural stands, are very limited. Recently, in the Baniyabhar Sal Regeneration Area belonging to Nepaljung Forest Development Project has been thinned out. The thinning works carried out in that area, the forest products obtained and the money realized at the constant rate (Fiscal Year 2000/2001) have been briefly described. It has been expected that this thinning exercise would be a reference for similar works in future.

\section{The approach}

Thinning works was carried out in October / November 2000 at the Sal Regeneration area of Baniyabhar forest. Sal regeneration area having the size of 0.25 hectare (ha) was laid out. Before thinning the species were enumerated and thcir diameter at breast height recordcd. Out of the total $(436$ trees), 235 trees of various species and having different diameters were thinned out leaving 201 trees $(53.9$ percent) to grow. Out of the thinned out trees, the maximum diameter at breast height (over bark) of Asna (Terminalia alata) was bigger $(42 \mathrm{~cm})$ than Sal (Shorea robusta) $(15 \mathrm{~cm})$ and others $(23 \mathrm{~cm})$.

\section{Findings}

\section{The thinning grade}

Heavy thinning was carried out removing many but not all codominant trees. It was thought that the heavier thinning would create temporary canopy gaps, which would accelerate crown expansion for the remaining trees. Looking at the original density of trees (1744) and the removed ones ( 53.9 percent), it may be very well anticipated that $D$ grade of thinning was employed.

\section{Composition of species}

The area could be categorized as Mixed Tropical Hardwood with Sal (Sborea robusta) and Asna (Terminalia alata) being the major tree species (Figure 1).

\section{Yield of forest products}

The thinning yielded 0.25 chatta of firewood, 28 koro of Asna, 16 Koro of Sal, and 11 Koro of Dhauti (Miscellaneous species) comprising a total of 10 cubic fect. Koros are small rimbers used for rafters and perlins for construction of small huts. Normally the size of koro is less than $10 \mathrm{~cm}$ diameter and up to $4 \mathrm{~m}$ length. These are obtained from saplings and top portion of felled trees. It also yielded 10 number of Balli (small sized timber, less than $25 \mathrm{~cm}$ in diamcter, used for constructions).

Figure 1: Proportion of trec species in thinning area

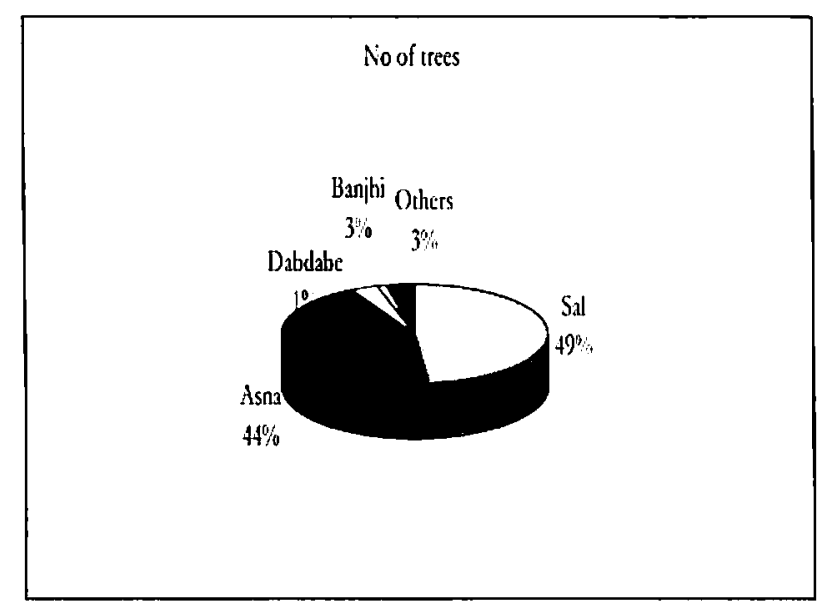

\section{Cost incurred}

Before thinning brush cutting activitics werc done, as the area was bushy. A total of 46 man-days were incurred in the thinning operations. The wage rate per labor was NRs 70 per day. Therefore, a total of NRs 3220 per hectare was incurred for the thinning activities. The breakdown of the costs were as follows:-

\begin{tabular}{ll}
\hline Activities & No. of man days \\
\hline Brush cutting & 8 \\
Actual thinning works & 20 \\
Chatta preparation & 18 \\
Total & 46 \\
\hline
\end{tabular}

'Chief, Foreign Aid Co-ordination Division, Ministry of Forests and Soil Conservation, Kathmandu, Nepal
2 Director General, Department of Forest Research and Sur

2 Director General, Department of Forest Research and Survey, Babar Mahal, Kathmandu, Ncpal 


\section{Revenue generated}

The revenue figure shows that a total of NRs 29,640 per hectare was generated from the thinning activities. The income generated from different products were as follows:-

\begin{tabular}{ll}
\hline Type of products & Income (NRs/ha) \\
\hline Fuclwood & 8,500 \\
Koro & 3,640 \\
Poles & 17,500 \\
Total & 29,640 \\
\hline
\end{tabular}

\section{Conclusions}

Thinning in natural forcst is one of the important silvicultural operations. It is expected that the trecs retained after thinning would get adequate light and moisturc and less competition for below ground nutrients there by the volume of these retained trees would be morc. As the thinning was carried out only in last October /November onc has to wait for the overall growth performance of the retained trees.
The thinning yield indicates that fuelwood and small construction timber are the major components from natural Terai mixed hardwoods. The income expenditure figure suggests that revenue generated is more in comparison to the expenditure. Initiation of thinning operations is not end itself. Growth data has to be continuously collected and monitored so as to examine the expected silvicultural out turns. It has been suggested that similar type of thinning works should be initiated in other sites having similar forest conditions.

\section{Expectations from the study}

As a very little work on thinning operations have been carried out in production forests, and grading on thinning have not been studied yet, this study is expected to provide useful information for similar futurc works. Such information will help carrying out thinning operations while implementing operational forest management plan. It has been expected that the result of the present study, although small in scalc, would be useful for field level officers and forest managers. 